\title{
Comprehensive Diagnostics of Musculoskeletal System Disorders in Sports Horses
}

\author{
Tatyana Sergeevna Ruzanova, Sergey Nikolaevich Mager, Nikolai Alekseevich Shkil, Elena Yurievna \\ Smertina, Anton Konstantinovich Sorokin
}

\begin{abstract}
The workwas aimed at studying the efficiency of the comprehensive examination of the limbs in sports horses for the presence of pathologies of the musculoskeletal apparatus.

The article presents the results of comprehensive diagnostics of the musculoskeletal system disorders in sports horses. In particular, the diagnostics involved a hematological study of the blood of horses, radiography, and ultrasonography of the limbs. The comprehensive diagnostic tests were performed according to the existing standard methods. The authors have found that the use of only one method of functional diagnostics may result in a false logic of the development of the pathogenesis of the musculoskeletal disorder in horses, and consequently in iatrogenesis, and further in the culling of high-value horses from sports. In the authors' opinion, verified diagnostics of the diseases of the musculoskeletal system in horses require the use of comprehensive diagnostic studies, which should include the data from the anamnesis, clinical examination, laboratory blood tests, and the results of ultrasonography and radiography.
\end{abstract}

Keywords : sports horses, equestrian sports, ultrasonography of tendons, radiography of limbs, hematologic tests of the blood.

\section{INTRODUCTION}

According to numerous studies, traumatism in sports horses is widely occurring and can reach $63.9 \%$, which is often the cause of osteoarticular pathologies. The effects of trauma result in chronic diseases of the joints, manifested by degenerative lesions of the articulation surfaces and surrounding tissues. In the conditions of heavy loads on horses in sports, the priority for veterinary specialists is timely and highly accurate diagnostics of these pathologies, which, in turn, in most cases determines the efficiency of treatment and further use of sports horses [1], [2].

Any injury of a distal segment of horse limbs can significantly limit or stop further sports career of the horse, and often is the cause of its death as a result of secondary diseases.

Revised Manuscript Received on October 30, 2019.

* Correspondence Author

Tatyana Sergeevna Ruzanova*, Novosibirsk State Agrarian University, Novosibirsk, Russia

Sergey Nikolaevich Mager, Siberian Research Institute of Animal Husbandry (SibNIPTIZh), Novosibirsk, Russia; Novosibirsk State Agrarian University, Novosibirsk, Russia

Nikolai Alekseevich Shkil, Novosibirsk State Agrarian University, Novosibirsk, Russia

Elena Yurievna Smertina, Novosibirsk State Agrarian University, Novosibirsk, Russia

Anton Konstantinovich Sorokin, Novosibirsk State Agrarian University, Novosibirsk, Russia

(C) The Authors. Published by Blue Eyes Intelligence Engineering and Sciences Publication (BEIESP). This is an open access article under the CC BY-NC-ND license (http://creativecommons.org/licenses/by-nc-nd/4.0/)

\section{LITERATURE REVIEW}

A. Peculiarities of examining the immunological status of sports horses

Hematological features of horses

In his studies, V. S. Sergienko states the following:

a. The same level of erythrocytes and leukocytes is found in male and female horses.

b. The concentrations of hemoglobin, hematocrit and the erythrocyte count tendto increase in pregnant mares.

c. The seasonal differences described in the studies are often not taken into account.

d. The level of reticulocytes does not change at rest. In the case of anemia, the level of reticulocytes will increase in the bone marrow. Assessing bone marrow response to anemia requires measuring the hematocrit at $3-5$ days intervals.

\section{B. Immunological indicators of blood in horses}

According to S. N. Mager [3], one of the important indicators of the blood coagulation system in horses is the activated partial thromboplastin time and the prothrombin time. The problem in assessing consists in the fact that the results of these tests may greatly vary, depending on the method and reagents used.

Activated partial thromboplastin time (aPTT) is $9.7-11.7$ sec, and it is $8.0-12.4$ sec.

An increase in the level of products of fibrin dehydration is observed in the case of DIC. According to Meyers and colleagues, 1982, normal values are less than $10 \mu \mathrm{g} / \mathrm{ml}$, and according to Johnstone and Crane, 1986, they are less than $20 \mu \mathrm{g} / \mathrm{ml}$. In the case of suspected congenital coagulopathy, specific coagulation factors should be identified. The concentration of clotting factors is expressed as a percentage of the reference sample. Normal values are $50 \%$ to $150 \%$.

Normal values of serum amyloid A for foals are less than 6 $\mathrm{mg} / \mathrm{ml}(<0.06 \mathrm{~g} / \mathrm{l})$. According to Stoneham and colleagues, 2001, the values exceeding $10 \mathrm{mg} / \mathrm{dl}(>0.1 \mathrm{~g} / \mathrm{l})$ indicate infection.

According to Takiguchi and colleagues, 1990, some studies reported that the normal values for C-reactive protein in horses amounted to $3.4-11.4 \mathrm{mg} / \mathrm{l}$. The values allowed \pm 2CO (standard deviation), $\mathrm{n}=10$.

\section{Biochemical parameters of horse blood}

Bromsulphalein clearance

Enjelking and colleagues (2005) used $4.4-5.1 \mathrm{mg}$ of bromsulphalein per one $\mathrm{kg}$ of body weight (b.w.). T1/2 was $2.2-4.1 \mathrm{~min}$, average $\pm 2 \mathrm{CO}, \mathrm{n}=10$.

ICG clearance 
Enjelking and colleagues (2005) used $0.8-1.1 \mathrm{mg}$ of ICG per one $\mathrm{kg}$ of b.w. T1/2 was $5.4-13.8 \mathrm{~min}$, average \pm $2 \mathrm{CO}, \mathrm{n}=10$. Parry and colleagues (2003) used $45 \mathrm{mg}$ of ICG per horse (400 - $500 \mathrm{~kg}$ of b.w.). T1/2 was $3.1-6.9$ min, limits: $\mathrm{n}=10$.

One of the important parameters for assessing the functional ability of the liver is determining the concentration of bile acids in the serum (and testing the tolerance to bile acids), which can be an alternative to the above tests.

As a rule, an increased concentration of bile acids is associated with reduced functionality of the liver.

Ammonia in the blood plasma of horses increases as the functionality of the liver reduces. This parameter is not as specific as bile acids, but it can also be useful in comprehensive diagnostics.

\section{The structural features of the musculoskeletal system of horses}

The main role in the static and dynamic functions of the musculoskeletal system of sports horses is played by the muscle tissues and their fascia (connective tissues), bones, nerves, joints, ligaments, and tendons, as well as by tendon bursa. Trauma may occur in one of these structures, and several structures at once.

The results of the studies by D. Hodgson, C. McGowan explain frequent ruptures of tendons in the area of their transition into the muscle fibers or at the point of attachment to the bone [4].

For instance, H. Clayton, P. Flood, D. Rosenstein [5] reported that displacement of the main structures of the musculoskeletal system relative to the longitudinal axis of the leg was prevented by transverse folds of the tendons and the digital flexors, annular ligament in the area of the first phalanx, the deep fascia, and its lateral ligaments.

For instance, Kainberger F., Mittermaier, F., Seidl G. reported that the area of the highest risk of damaging the superficial digital flexor, the common digital extensor, and the lateral digital extensor was the middle third of the tendon; of the deep digital extensor — the middle third and the structures located on the circumference of forefoot; the third interosseous muscle.

\section{E. Classification of equine tendon diseases}

According to Dyson S. J., Dik K. J., injuries of sports horses mainly occur in the musculoskeletal system, but most often - on the distal limbs: the muscles, the tendons, and the joints.

According to the research of P. H. Patterson, C. N. Coon, I. M. Hughes, during competitions without obstacles, horses often get the third interosseous muscle hurt, and during competitions with obstacles - the superficial and deep digital flexor, and the distal sesamoid ligaments.

In the trotting race, the suspensory ligament of the forefoot, digital flexors on the front legs, suspensory ligaments of the forefoot on the hind legs are injured. In multidiscipline competitions, horses getinjured the suspensory ligament of the forefoot, flexors, and extensors of the digits. During showjumping, tendons with perforation, the additional ligament of the inner tendon the digital flexor (or carpal fusion), get injured. Old or sedentary horses get an injury of the internal tendons digital flexor and carpal fusion [6].
The main factors that result in inflammation are sprains, burstings, and ruptures of tendons. They also include bruises, and injuries by various piercing and cutting items [7], [8].

\section{F. Classification of equine joints diseases:}

1. Closed traumatic injuries of the joints:

-bruising of the joint; this injury is characterized by a blunt trauma of the joint without compromising the integrity of the surface epithelium;

-sprain — a reversible breaking of the bond of the articular surfaces relative to the axis of each other with a moderate detachment of the ligaments and the capsule of the joint;

-joint dislocation, which is characterized by a reversible but persistent disturbance of the articular surfaces relative to the axis of each other, expressed by a severe injury and partial tearing of ligaments, and violation of the integrity of the joint capsule. If the articular surfaces lose contact to a marked distance, whereby their edges are not in contact, the dislocation is called complete; in case of an incomplete dislocation, the surfaces remain partly in contact;

-periarticular fibrosis is characterized by chronic overgrowing of connective (fibrous) tissues into the periarticular tissues (subcutaneous tissues, skin). With that, the joint itself is not changed degeneratively; and

-fibrous periarthritis is a resistant chronic inflammation in the joint capsule accompanied by degenerative changes of the joint and its surrounding tissues, and in ligaments.

2. Open injuries of the joints.

-Wounds of the joints are the damages to the structures of the joint characterized by open gaping wound edges, and impaired integrity of surrounding areas.

3. Joints inflammation - arthritis.

Join inflammations are classified by the type of the course of the disease and the exudate properties:

- aseptic arthritides,

- infected arthritides,

- panarthritides,

- capsular purulent arthritides, and

- rheumatism.

4. Chronic inflammatory and degenerative lesions of joints:

-chronic deforming arthritis. It is also known as deforming osteoarthritis;

-arthrosis. It is a chronic, persistent irreversible degenerative change in the joint, the articular cartilage and other structures of the joint.

5. Ankylosis is the loss of the joint motor function due to inflammatory, degenerative, and other diseases. It is characterized by complete loss of articular tissues and its replacement with fibrous connective tissues; and

6. Contracture is the persistent limitation of joint mobility due to the retraction of surrounding tissues byproliferating connective tissues.

\section{G. Ultrasonographic study of horse limbs}

For preventing diseases of the distal extremities in horses, the conditions of keeping and feeding should be observed.

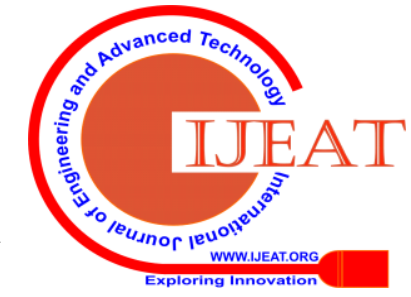


These include rational training, balanced daily diet with optimal content of protein, macro- and microelements, and vitamins. Horses need healthy daily exercise with a uniform dose of UV irradiation. Horse injuries in the conditions of keeping and during training should be prevented and avoided, and safe transportation of horses must be organized. Training should be performed evenly with the growth and development of the horse, thereby preventing excessive strain on the structures of distal extremities [9].

Using ultrasound examination, foreign bodies and abscesses may be identified with high accuracy. That is why the use of comprehensive visual research methods promotes more accurate and comprehensive diagnostics and identifications of the reason for limping.

\section{H. X-ray examination of horse limbs}

Radiography is a constantly evolving science, as more powerful and modern equipment becomes available, providing more diagnostic capabilities to veterinarians. In some areas, however, no works have been published, or the published information is contradictory. In this text, the current terminology is used. The X-ray view is described using the method proposed by the American College of Veterinary Radiologists. Figure 1 shows the terms used later in the text [10].

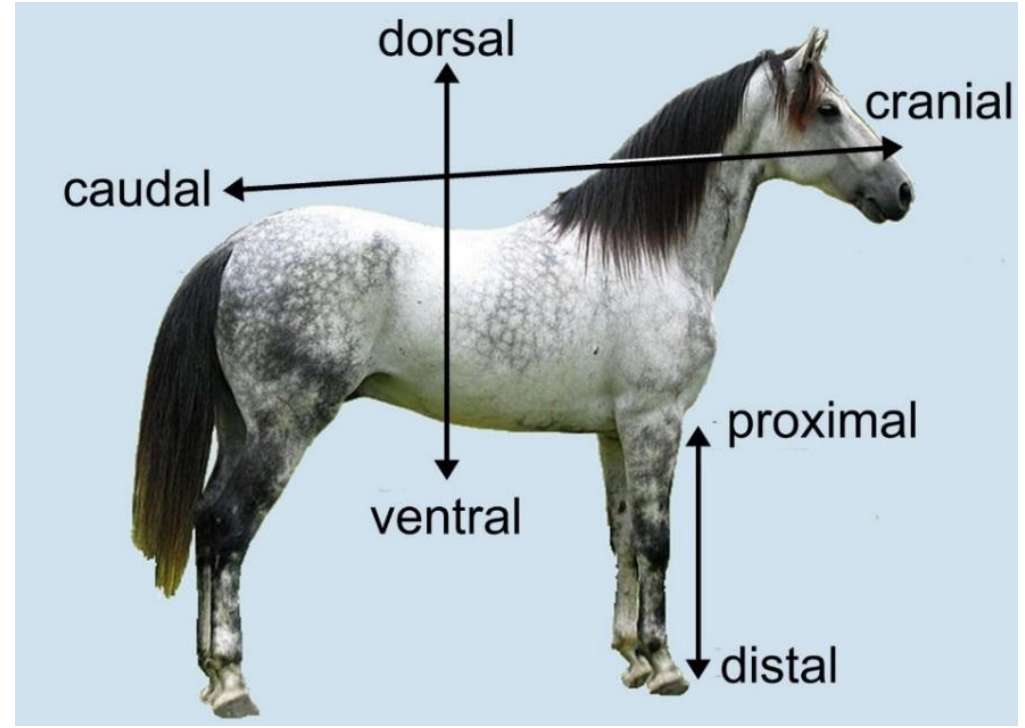

Fig. 1. Anatomical areas

Hypothesis is as follows: efficient examination of sports horses for early detection of pathologies in the musculoskeletal system and prescribing the most efficient pathogenetic therapy should include studying not only the limbs (ultrasound and radiography) but also the hematological, the immunological and the biochemical status of each horse.

\section{METHODS}

\section{A. General description}

The objects of the study were the Trakehner horses. The study was performed on 40 horses at the age of $8-12$ years based on the equestrian sports training center in Novosibirsk. At the time of the study, all horses had daily training according to the regulations of training. The material for the study was blood. The blood was taken from the jugular vein, without the use of sedation, using the vacuum method using tubes with EDTA.

For the experiment, 40 horses were divided into the reference and the experimental groups, 20 horses in each.

The experimental group included the horses with the pathology of the extremities diagnosed through injections of phenylbutazone. The reference group included the horses with the pathology of the extremities diagnosed through ultrasonography and radiography that did not receive intravenous injections of phenylbutazone. All horses ultrasonography and radiography that received intravenous

were not younger than 10 and not older than 15 years. All of them were subjected to the same load and participated in competitions of the same kind.

During the experiment, the following parameters were taken into account: ESR by Panchenkov, the erythrocytes count, the leukocytes count, the level of hemoglobin, hematocrit, neutrophils (stab, segmented), eosinophils, basophils, lymphocytes, and monocytes. [11]

The obtained data were statistically processed by the method of calculating the mean arithmetic (M) and standard errors (m). In the tables, the information is presented as $\mathrm{M} \pm$ $\mathrm{m}$. The level of significance of the differences of variational series was assessed by the parametric Student's t-test.

The complex of diagnostic measures with the use of the methods of ultrasonic scanning and radiography of the limbs of the horses was performed at the Center for Equestrian Sports Training in Novosibirsk between November 2015 and October 2017.

At the time of the diagnostic study, all horses had daily training according to the regulations of training (Fig. 5).

For ultrasound scanning of the horses' tendons, ultrasound apparatus MindRay DP-50 with a high-frequency (7.5 MHz) linear transducer was used. The study was performed according to the procedures set out in the manuals of $\mathrm{M}$. V. Zhukova, Y. N. Bogin, I. E. 


\section{Comprehensive Diagnostics of Musculoskeletal System Disorders in Sports Horses}

Inozemtseva, L. V. Matveeva, N. N. Khanzhina, and others. [12]. For identifying the location of abnormal foci in the tendon-ligament structures, the scheme of conditional dividing distal extremities of the horses into zones was used.

This methodology is the international standard for ultrasound scanning of the tendons. In the metacarpus, there are three zones (1 to 3 ), and in the metatarsus, there are four zones (1 to 4), with subzones A and B. The ultrasonographic structure of the damaged tendons and ligaments was compared to the one ofthe healthy limb (Fig. 2).

One of the main methods that allow judging about the changes in the musculoskeletal system of animals that occur in the body under the influence of various pathological factors is radiography. For instance, that this method significantly improved diagnosing diseases of the phalanges in horses. Domestic and foreign veterinary literature contains a lot of information about radiological diagnostics of pathologies of the musculoskeletal system in horses, but there are also several gaps and inaccuracies in respect of some diagnostic parameters of the X-ray examination associated with the objective sides of the X-ray examination. However, everyday clinical practice needs the most accurate diagnostics and efficient therapeutic methods.

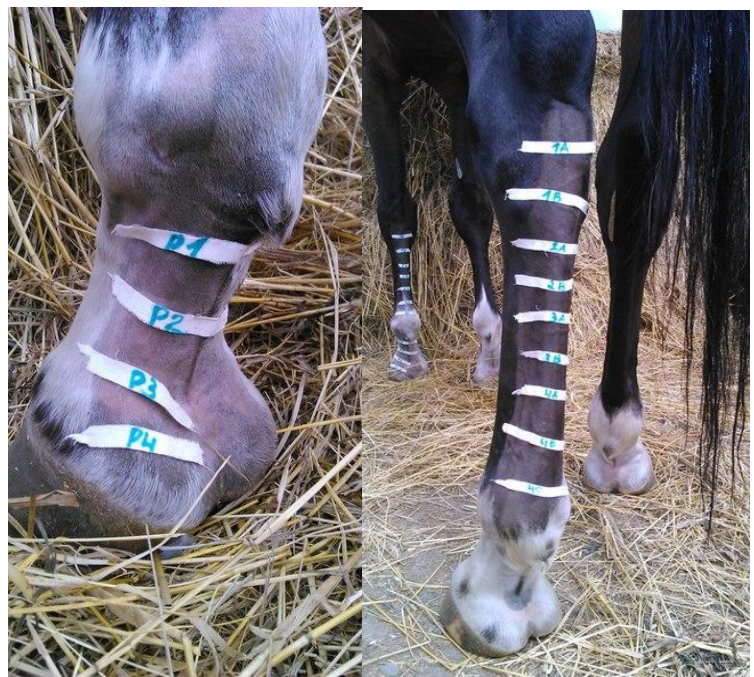

Fig. 2. Layout of the zones for scanning in the area of the metacarpus, the metatarsus, and the hopple.

Radiographic examination of the limbs of the horses was performed using apparatus EcoRay ORANGE-1040F according to the generally adopted radiological methods stated in the manual of B. V. Ousha [10].

Diagnostic studies for the presence of osteoarticular pathology in the 40 studied horses were performed consistently with the use of radiography, ultrasound examination of the distal sections of limbs, as well as with processing and systematization of the data from differential diagnostics of the results of studies for verifying the diagnosis.

The results of differential diagnostics were grouped into a table with the use of standard office application Microsoft Excel for statistical processing.

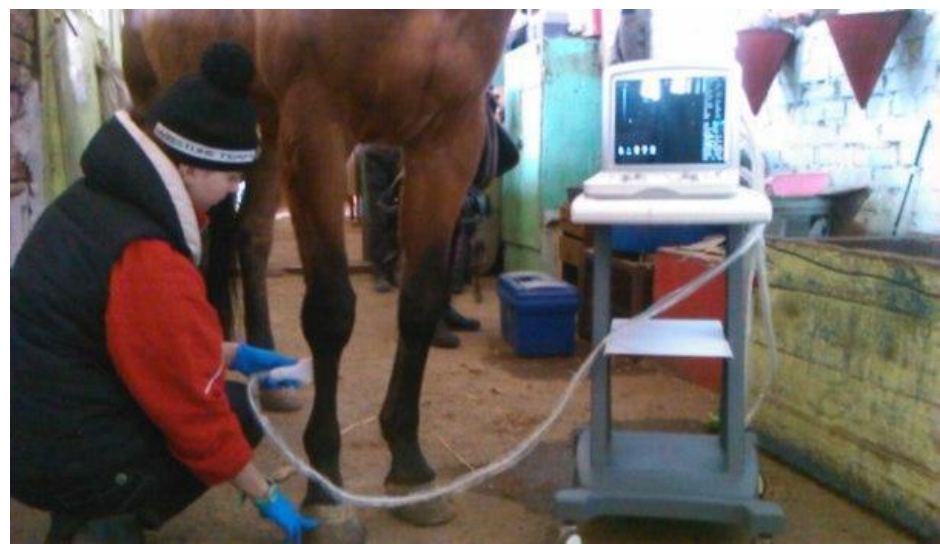

Fig. 3. Performing the ultrasonographic examination of the distal limb of the horse

\section{B. Algorithm}

After ultrasonography and X-ray examination, the horses were divided into two groups: experimental and reference ones, 20 horses in each.

The first experimental group contained the horses with diagnosed abnormalities of the tendon-ligament apparatus and bones and joints (fractures, arthritides)

The reference group included 20 clinically healthy horses. All the horses involved in the study had the level of Creactive protein determined before and after training.

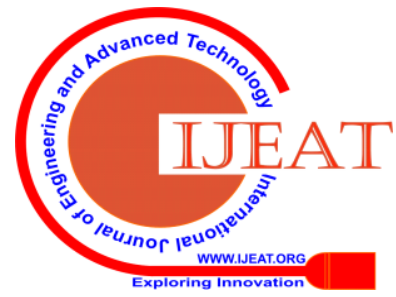


The obtained results were compared to the normal values provided in the literature $(3.4-11.4 \mathrm{mg} / \mathrm{l})$.

\section{RESULTS}

\section{A. The results of studying the immunological state} of sports horses

The results are shown in Fig. 4.

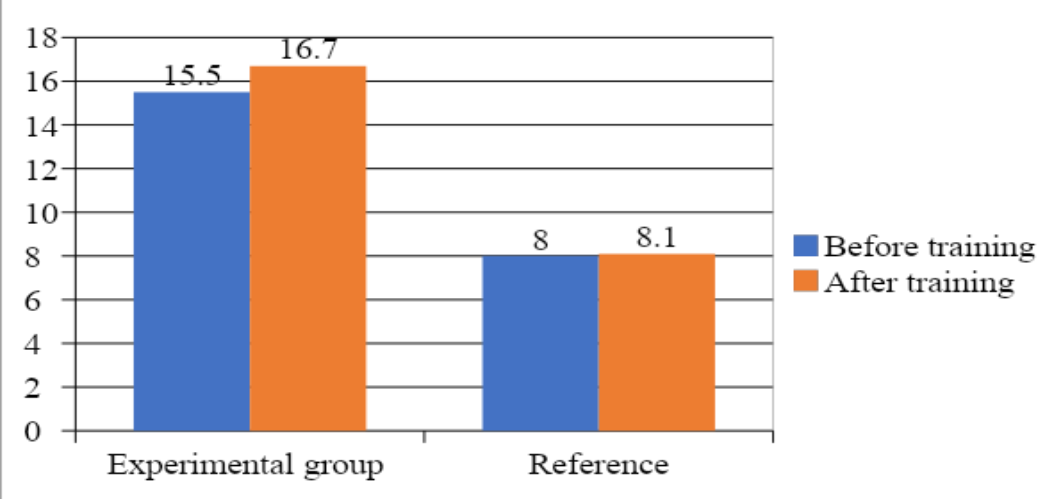

Fig. 4. Values of C-reactive protein in sports horses

Thus, from the data in Figure 4, one can see that the most significant changes in the level of C-reactive protein occurred in the animals with abnormalities of osteoarticular structures.

With that, no differences were found between concentration before and after the training.

Also, less significant changes in the level were found in the sports horses with abnormalities of the tendon-ligament apparatus; however, a natural increase was observed in this group after training, which was associated with the progression of the acute phase of inflammation under loads, and, as a consequence,with an increased level of the Creactive protein in the serum.

In the reference group of healthy horses, no significant changes were found, compared to the normal concentration of this value.

B. The results of X-ray and ultrasonographic examination of the distal segments of limbs in horses

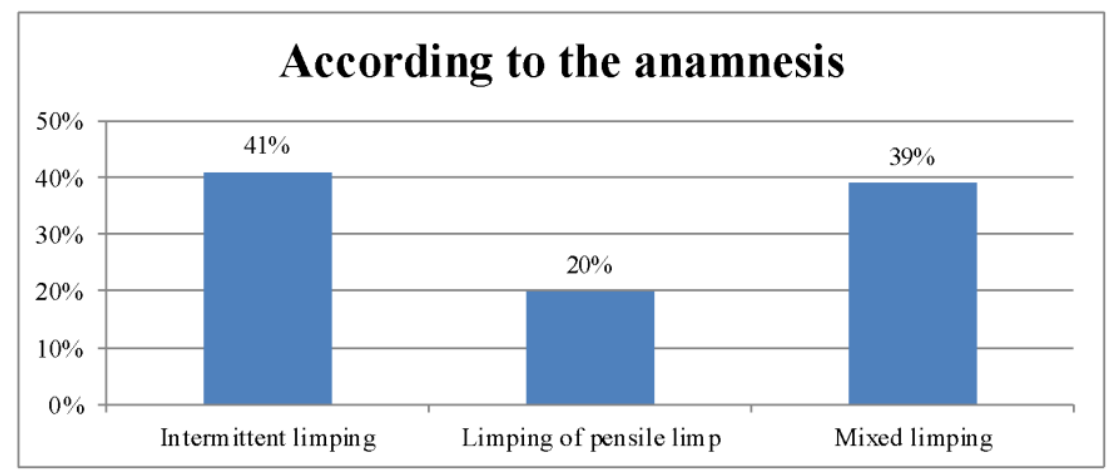

Fig. 5. Differential diagnostics of the type of limping in the horses involved in the experiment

Ultrasound diagnostics have great potential in detecting morphological changes in the tendons and tendinous structures, which gives an opportunity of making a more accurate clinical diagnosis for the presence of pathologies in the musculoskeletal system of sports horses.

The literature contains a lot of information about confirming ultrasound diagnostics by the clinical, anatomical and histological methods [13], [11].

In order to detect abnormalities of the tendon-ligament apparatus of the experimental horses, the authors performed an ultrasonographic examination of the distal segments of limbs (Fig. 3, 11, 12).

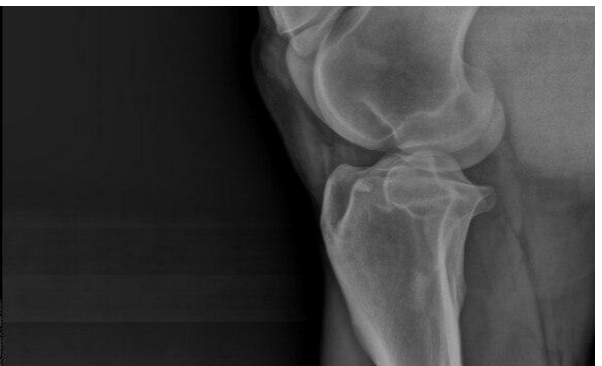

Fig. 6. Lateral projection of the left pelvic limb of a normal horse (the knee joint) 


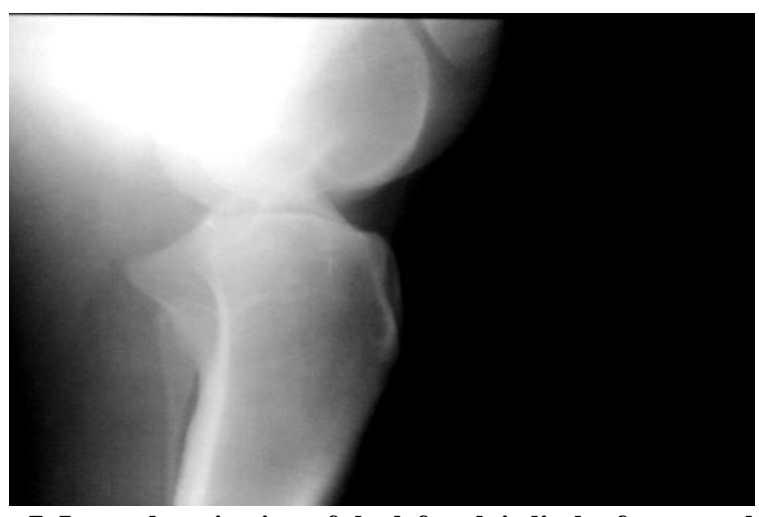

Fig. 7. Lateral projection of the left pelvic limb of a normal horse (the knee joint)

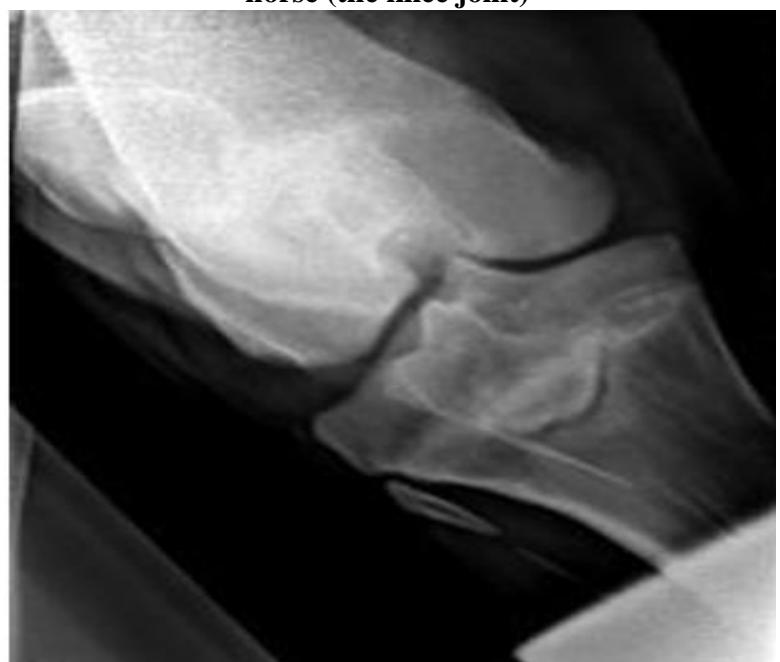

Fig. 8 (a). Straight projection of the knee joint. The arthrolith or spikes pathology

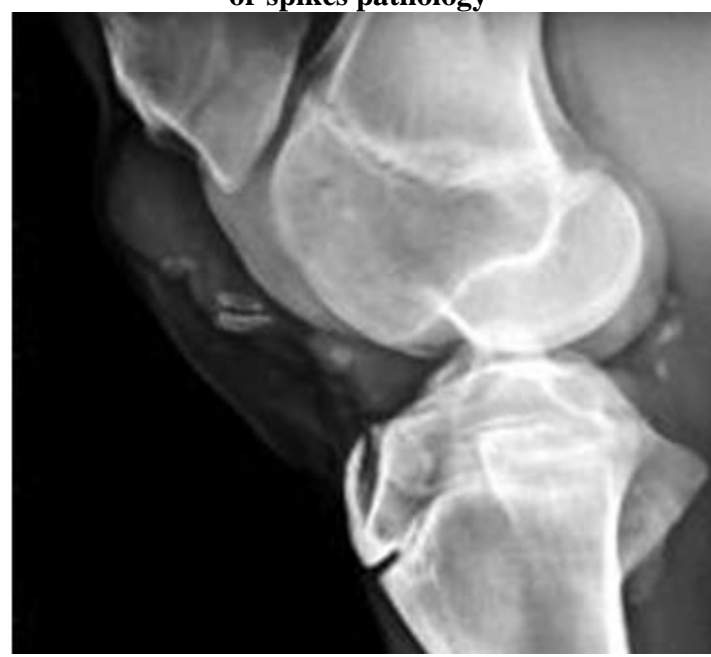

Fig. 8 (b). Straight projection of the knee joint. The arthrolith or spikes pathology

The breakdownis inflammation of the tendons of the digital flexor (often the superficial digital flexor, sometimes the deep digital flexor), or the interosseous middle muscle caused by partial or complete rupture of the tendon fibers due to injuries (sprains). It is manifested as thickening of the back surface of the metacarpus, which, if viewed from aside, has the shape of an arc (Fig. 10).

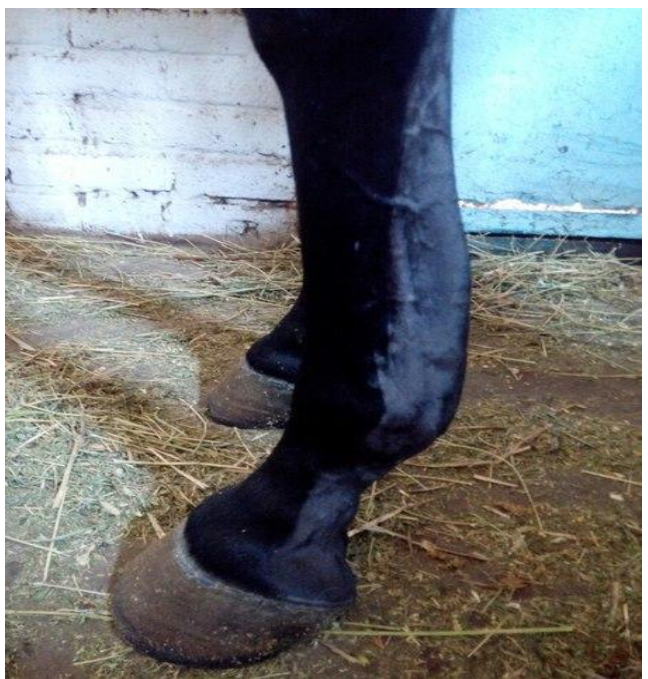

Fig. 10. Breakdown

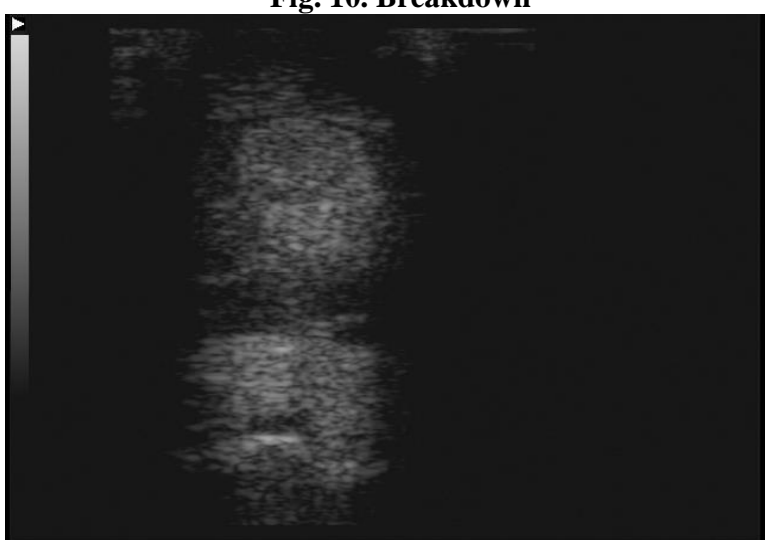

Fig. 11. The ultrasonogram characterizes the loss of the tendon structure. A noticeable nearly two times increase is seen in the size of SDFand DDF.

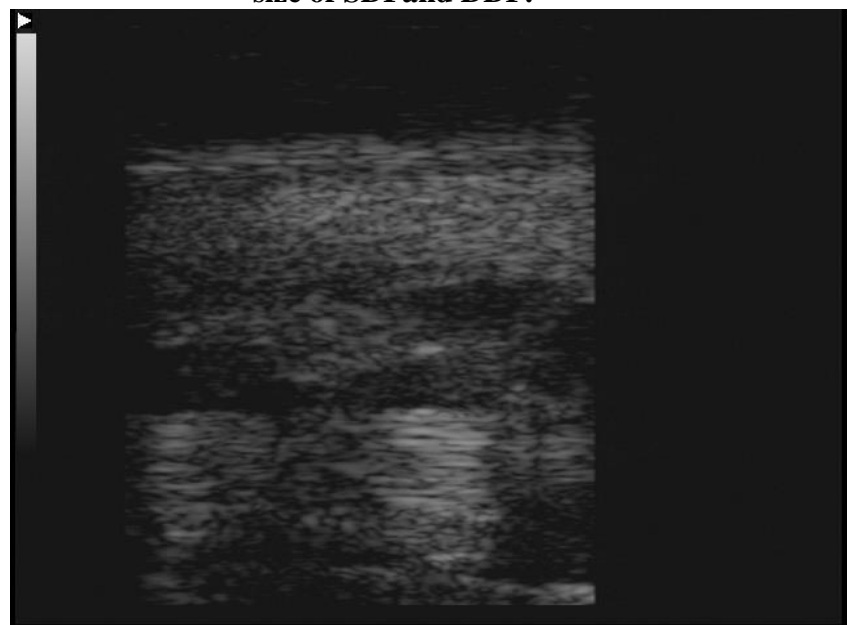

Fig. 12. Absence of linear striation. The structure is heterogeneous with large areas of anechogenicity.

Further, the authors made a comparative analysis of using the methods of X-ray examination and ultrasonography in comprehensive diagnostics of pathologies in the musculoskeletal system of horses (Fig. 2.9.2).

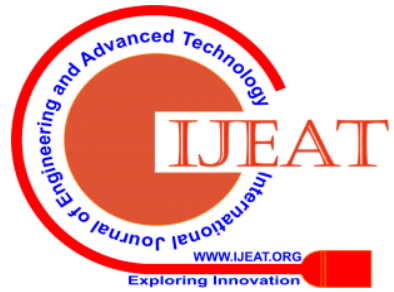




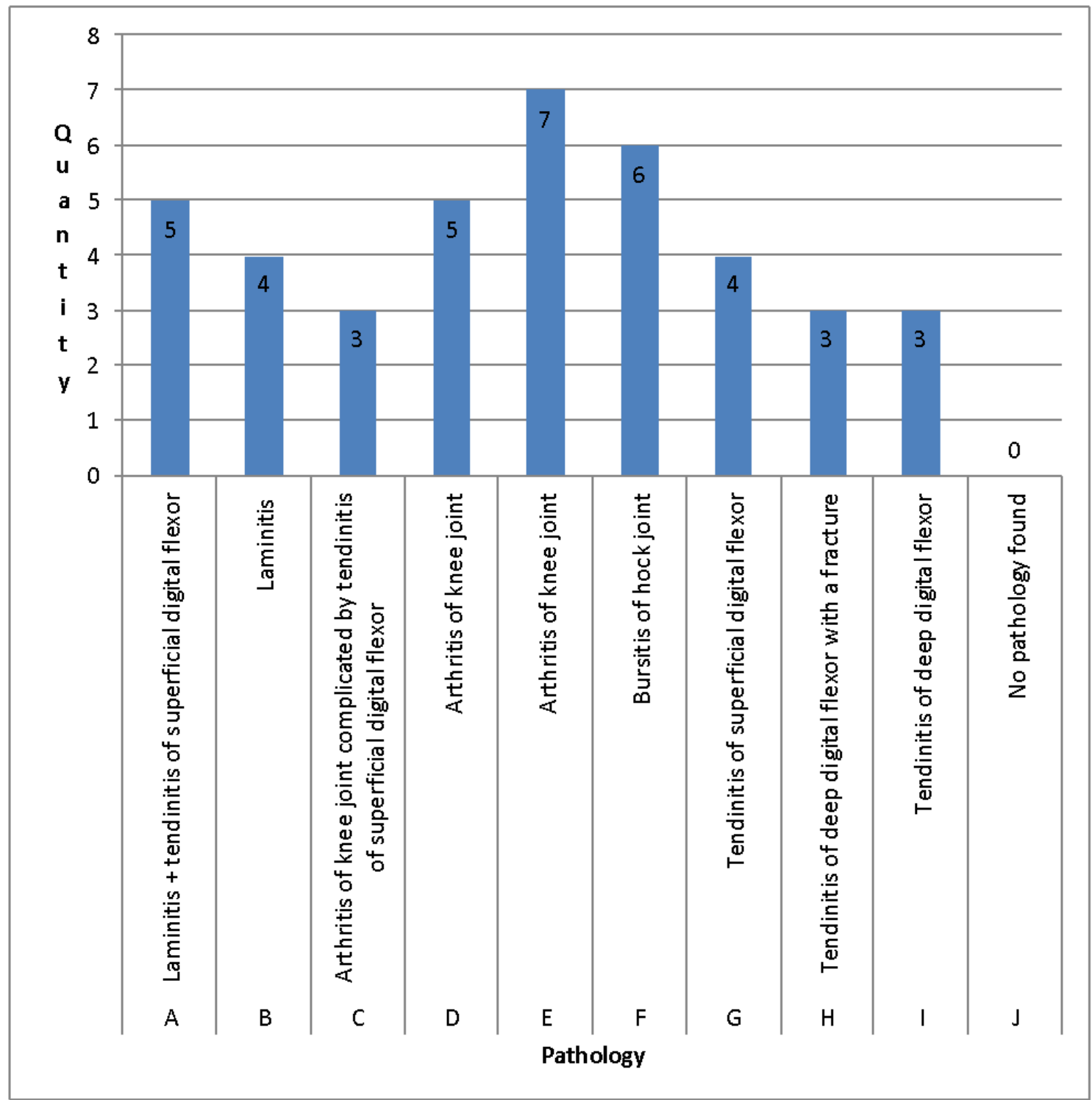

Fig. 13. The results of comprehensive use of the methods of $X$-ray examination and ultrasonography in comprehensive diagnostics of pathologies in the musculoskeletal system of horses

From the anamnesis, clinical symptoms and changes detected by ultrasonography and X-ray examination (Fig. 6, $7,8,9)$ of the experimental horses, it was found that all 40 animals in the experimental group with symptoms of limping in the anamnesis, and at the time of the clinical examination, had various pathologies of the musculoskeletal system, in particular, five (12 \%) horses had laminitis complicated by tendinitis of the superficial digital flexor; four $(10 \%)$ horses had laminitis without complications, six (15\%) horses had tendinitis of the superficial digital flexor without complications, three (8 \%) horses had knee arthritis complicated by tendonitis of the deep digital flexor, and four (10 \%) horses had tendinitis of the deep digital flexor without complications. Also, five (12\%) horses had knee arthritis without complications, seven (17 \%) horses had bursitis of the ankle joint; fractures of various degrees of complexity with concomitant tendovaginitis of the deep digital flexor were diagnosed in three (8\%) horses, and three (8\%) horses had tendovaginitis of the deep digital flexor without complications.

Thus, the authors found that a comprehensive examination of the horses with abnormalities of the musculoskeletal system provided an opportunity to examine in more detail the pathological processes that occured in the traumatized limbs of the horses, to identify comorbidities and, consequently, to prescribe proper pathogenetic treatment.

Table 1: The results of the clinical studies of the blood

\begin{tabular}{|c|c|c|}
\hline Hematologic indicators & Experiment & Reference \\
\hline Leukocytes & $16.38 \pm 0.52^{* * *}$ & $8.43 \pm 0.17$ \\
\hline Segmented neutrophils & $29.85 \pm 0.66^{*}$ & $37.64 \pm 0.28$ \\
\hline Hematocrit & $68.95 \pm 1.95^{* *}$ & $59.35 \pm 0.83$ \\
\hline
\end{tabular}

Note. Hereinafter: $* \mathrm{P}<0.05,{ }^{* *} \mathrm{P}<0.01,{ }^{* * *} \mathrm{P}<0.001$ to the reference 
Table 2: The results of the biochemical studies

\begin{tabular}{|c|c|c|}
\hline Biochemical indicators & Experiment & Reference \\
\hline Alkaline phosphatase & $266 \pm 7.45^{* * *}$ & $85 \pm 1.9$ \\
\hline Calcium & $4.04 \pm 0.03^{* *}$ & $2.64 \pm 0.04$ \\
\hline Phosphorus & $1.98 \pm 0.008^{*}$ & $1.54 \pm 0.019$ \\
\hline
\end{tabular}

Note. Hereinafter: ${ }^{*} \mathrm{P}<0.05,{ }^{* *} \mathrm{P}<0.01,{ }^{* * *} \mathrm{P}<0.001$ to the reference

In the biochemical analysis of the blood of experimental and reference groups, 15 parameters were determined: alanine aminotransferase, aspartate aminotransferase, lactate dehydrogenase, lipase, amylase, total protein, glucose, urea, creatinine, phosphorus, potassium, calcium, magnesium, alkaline phosphatase, and gamma-glutamyltransferase.

Statistical processing of the obtained Student'st-test data revealed veracious differences between the experimental and the reference groups by three indicators: alkaline phosphatase, phosphorus, calcium (Tab 1, 2).

The other 12 indicators were within the physiological norm and did not have significant shifts, compared to the reference group.

Analysis of the obtained data showed that a veracious increase in the content of alkaline phosphatase, calcium, and phosphorus was associated with osteoarticular pathology, namely with fractures in the horses in theexperimental group. The increase in these indicators is evidence of the second phase of the fracture, which is characterized by the formation of osteotylus from the connective tissues.

On the background of diseases of the musculoskeletal system, hematological parameters undergo significant changes: thus, in the horses from the reference group, a persistentincrease in the number of leukocytes and segmented neutrophils was observed along with an increased hematocrit count, which is a marker of stress in case of injury and dehydration, which is associated with inflammatory diseases of the extremities.

Given the significant changes in the hematological parameters, diseases of the limbs of sports horses cannot be regarded as a local process; this processinvolves the entire organism.

Studying the hematological profile should not be overlooked in diagnostics (Tables 4, 5).

Hematological analysis (Table 3) should be included in the examination record of the horses with injured limbs.

The main indicators of blood in the experimental and the reference groups are shown in Tables 1 and 2 .

Analysis of the data in Table 3 shows a persistent decrease in the ESR, erythrocytes count, hematocrit and an increase in the leukocyte count with a shift to the left, lymphocytosis. It should be noted that in all these cases, the tendency to changes in the indicators was reliable.

Table 3:Hematological status of the sports horses in the experimental group

\begin{tabular}{|c|c|c|c|c|c|c|c|c|c|c|c|c|c|}
\hline $\begin{array}{l}\text { Experi } \\
\text { ment }\end{array}$ & $\begin{array}{l}\text { ESR } \\
\text { by } \\
\text { Panch } \\
\text { enkov } \\
\text { (mm/h } \\
\text { our) }\end{array}$ & $\begin{array}{l}\text { Erythr } \\
\text { ocytes } \\
10 \wedge 12 / \\
1\end{array}$ & $\begin{array}{l}\text { Leuk } \\
\text { ocytes } \\
10 \wedge 9 / \\
1\end{array}$ & $\begin{array}{l}\text { Hemo } \\
\text { globin } \\
\text { g/l }\end{array}$ & $\begin{array}{l}\text { Hema } \\
\text { tocrit } \\
\%\end{array}$ & $\begin{array}{l}\text { Avera } \\
\text { ge } \\
\text { Volum } \\
\text { e } \\
\text { Erythr } \\
\text { ocytes } \\
\text { fl } \\
\end{array}$ & $\begin{array}{l}\text { Plat } \\
\text { elets } \\
10 \wedge \\
9 / 1\end{array}$ & $\begin{array}{l}\text { Stab } \\
\text { Neutr } \\
\text { ophils } \\
\%\end{array}$ & $\begin{array}{l}\text { Segm } \\
\text { ented } \\
\text { neutr } \\
\text { ophils } \\
\%\end{array}$ & $\begin{array}{l}\text { Eosin } \\
\text { ophils } \\
\%\end{array}$ & $\begin{array}{l}\text { Baso } \\
\text { phils } \\
\%\end{array}$ & $\begin{array}{l}\text { Lymp } \\
\text { hocyte } \\
\text { s } \\
\%\end{array}$ & $\begin{array}{l}\text { Mon } \\
\text { ocyte } \\
\text { s } \\
\%\end{array}$ \\
\hline $\begin{array}{l}\text { NOR } \\
\text { M }\end{array}$ & $10-30$ & 6.0-9.0 & $7-11$ & $80-140$ & $35-40$ & $34-58$ & $\begin{array}{l}200- \\
500\end{array}$ & $0-6$ & $54-65$ & $0-4$ & $\mathbf{0}$ & $16-43$ & $1-6$ \\
\hline 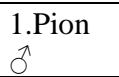 & 7 & 3.50 & 15.25 & 99 & 31.0 & 54.6 & 137 & 2 & 62 & 3 & 0 & 47 & 6 \\
\hline $\begin{array}{l}2 . \\
\text { Sokol } \\
\text { J }\end{array}$ & 5 & 2.44 & 15.34 & 115 & 30.0 & 48.3 & 137 & 4 & 62 & 3 & 0 & 27 & 6 \\
\hline $\begin{array}{l}3 . \\
\text { Stapler } \\
\bar{\lambda}\end{array}$ & 8 & 5.40 & 17.80 & 135 & 28.0 & 48.3 & 154 & 4 & 68 & 0 & 0 & 27 & 8 \\
\hline $\begin{array}{l}4 . \\
\text { Chocol } \\
\text { adka }+\end{array}$ & 7 & 4.56 & 13.20 & 87 & 34.0 & 50.0 & 127 & 2 & 68 & 2 & 0 & 20 & 2 \\
\hline $\begin{array}{l}5 . \\
\text { Hankh } \\
\text { or } \hat{\delta}\end{array}$ & 6 & 3.48 & 17.15 & 80 & 30.0 & 53.1 & 125 & 4 & 65 & 2 & 0 & 54 & 4 \\
\hline $\begin{array}{l}6 . \\
\text { Hopph } \\
\text { erd }{ }^{\lambda}\end{array}$ & 6 & 2.40 & 18.25 & 98 & 27.0 & 53.1 & 125 & 4 & 58 & 2 & 0 & 20 & 8 \\
\hline $\begin{array}{l}7 . \\
\text { Lekon } \\
\text { de } \\
\text { Lille }{ }^{\wedge} \\
\end{array}$ & 3 & 4.57 & 15.40 & 145 & 35.0 & 45.7 & 110 & 4 & 59 & 2 & 0 & 20 & 6 \\
\hline
\end{tabular}




\begin{tabular}{|c|c|c|c|c|c|c|c|c|c|c|c|c|c|}
\hline $\begin{array}{l}8 . \\
\text { Pininfa } \\
\text { rina }+\end{array}$ & 5 & 4.50 & 17.76 & 80 & 29.0 & 30.7 & 140 & 4 & 68 & 2 & 0 & 48 & 6 \\
\hline $\begin{array}{l}9 . \\
\text { Tuz } \widehat{ }{ }^{\wedge}\end{array}$ & 3 & 3.88 & 20.10 & 120 & 25.0 & 28.9 & 100 & 0 & 67 & 2 & 0 & 56 & 4 \\
\hline $\begin{array}{l}10 . \\
\text { Princes } \\
\text { s } \\
\text { Gaya } 9\end{array}$ & 3 & 3.90 & 19.34 & 125 & 30.0 & 30.7 & 115 & 0 & 60 & 3 & 0 & 50 & 2 \\
\hline $\begin{array}{l}11 . \\
\text { Flashô }\end{array}$ & 3 & 3.87 & 17.45 & 110 & 35.0 & 50.8 & 145 & 0 & 62 & 0 & 0 & 52 & 2 \\
\hline $\begin{array}{l}12 . \\
\text { Pagani } \\
\text { ni }{ }^{\widehat{N}}\end{array}$ & 7 & 4.09 & 13.46 & 96 & 30.0 & 53.2 & 180 & 2 & 60 & 2 & 0 & 54 & 6 \\
\hline $\begin{array}{l}13 . \\
\text { Probles } \\
\mathrm{k}\end{array}$ & 7 & 4.57 & 13.30 & 134 & 34.0 & 45.7 & 134 & 4 & 57 & 0 & 0 & 54 & 6 \\
\hline $\begin{array}{l}14 . \\
\text { Madrid } \\
\lambda\end{array}$ & 8 & 4.60 & 12.90 & 140 & 33.0 & 54.7 & 137 & 6 & 69 & 0 & 0 & 54 & 6 \\
\hline $\begin{array}{l}15 . \\
\text { Orel }{ }^{\star}\end{array}$ & 9 & 3.98 & 15.67 & 115 & 28.0 & 45.5 & 137 & 6 & 65 & 3 & 0 & 58 & 8 \\
\hline $\begin{array}{l}16 . \\
\text { Barkha } \\
\text { t }{ }^{\lambda}\end{array}$ & 5 & 5.40 & 17.89 & 95 & 27.0 & 34.5 & 156 & 2 & 63 & 2 & 0 & 50 & 6 \\
\hline $\begin{array}{l}17 . \\
\text { Garwa } \\
\text { yổ }\end{array}$ & 7 & 5.76 & 14.30 & 100 & 29.0 & 30.8 & 197 & 4 & 75 & 2 & 0 & 48 & 4 \\
\hline $\begin{array}{l}18 . \\
\text { Tyna오 }\end{array}$ & 3 & 3.40 & 20.87 & 90 & 24.0 & 27.9 & 115 & 0 & 60 & 0 & 0 & 56 & 8 \\
\hline $\begin{array}{l}19 . \\
\text { Palana } \\
\text { 오 }\end{array}$ & 4 & 4.34 & 15.46 & 140 & 34.0 & 34.0 & 186 & 2 & 58 & 2 & 0 & 45 & 4 \\
\hline $\begin{array}{l}20 . \\
\text { Cosmo } \\
\text { star }\end{array}$ & 3 & 4.30 & 17.5 & 110 & 28.0 & 35.0 & 160 & 2 & 58 & 2 & 0 & 45 & 4 \\
\hline
\end{tabular}

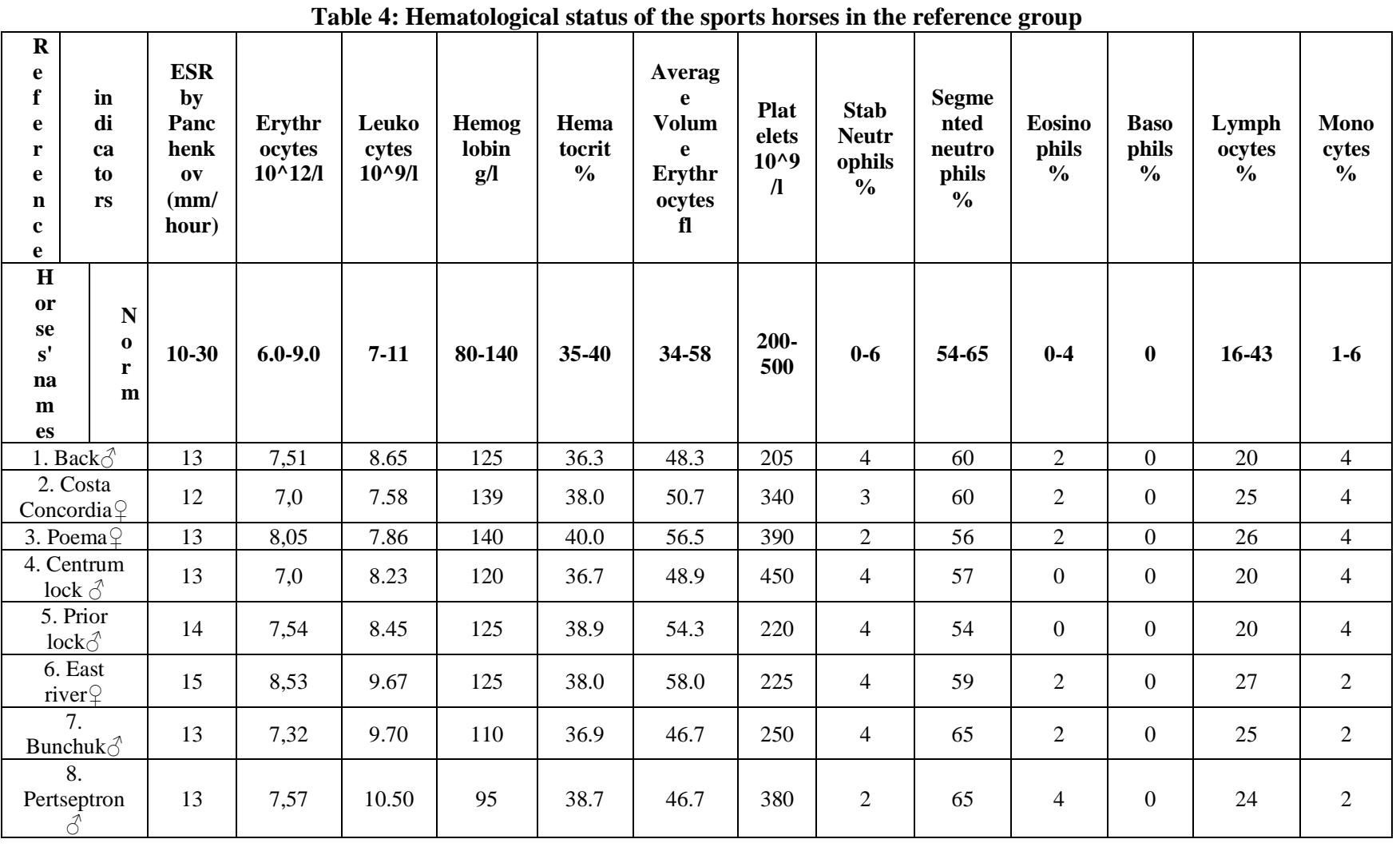

Retrieval Number: A2104109119/2019®BEIESP DOI: 10.35940/ijeat.A2104.109119

Journal Website: www.ijeat.org
Published By:

Blue Eyes Intelligence Engineering 6361 


\begin{tabular}{|c|c|c|c|c|c|c|c|c|c|c|c|c|c|}
\hline 9. Сymeia + & 15 & 8,56 & 8.78 & 100 & 39.6 & 43.9 & 300 & 2 & 60 & 0 & 0 & 20 & 4 \\
\hline $\begin{array}{l}\text { 10. Costa } \\
\text { Rica }{ }^{\circ}\end{array}$ & 14 & 8,08 & 7.58 & 110 & 36.2 & 42.1 & 270 & 2 & 59 & 0 & 0 & 16 & 4 \\
\hline $\begin{array}{c}\text { 11. Dream } \\
\text { Boy }{ }^{\lambda}\end{array}$ & 13 & 7,31 & 7.60 & 125 & 36.0 & 40.0 & 340 & 4 & 57 & 2 & 0 & 18 & 4 \\
\hline $\begin{array}{c}12 . \\
\text { Versailles }{ }^{\lambda} \\
\end{array}$ & 13 & 8,04 & 8.90 & 135 & 35.8 & 45.6 & 450 & 4 & 62 & 2 & 0 & 27 & 6 \\
\hline $\begin{array}{c}13 . \\
\text { Starfisho }\end{array}$ & 13 & 7,52 & 9.67 & 120 & 35.0 & 47.9 & 400 & 4 & 63 & 4 & 0 & 34 & 2 \\
\hline $\begin{array}{c}14 . \\
\text { Sunway } \widehat{C}\end{array}$ & 17 & 7,5 & 10.0 & 125 & 40.0 & 39.0 & 390 & 6 & 65 & 4 & 0 & 20 & 2 \\
\hline $\begin{array}{c}15 . \\
\text { Cenzura } 9\end{array}$ & 14 & 8,0 & 9.54 & 135 & 39.0 & 35.6 & 380 & 6 & 58 & 4 & 0 & 37 & 4 \\
\hline $\begin{array}{c}16 . \\
\text { Tamerlan } \widehat{O}\end{array}$ & 13 & 7,0 & 7.98 & 105 & 37.6 & 47.8 & 370 & 4 & 65 & 0 & 0 & 29 & 4 \\
\hline 17. Irma $Q$ & 13 & 8,0 & 8.56 & 115 & 38.7 & 49.7 & 270 & 2 & 54 & 2 & 0 & 30 & 2 \\
\hline 18. Agat ${ }^{\widehat{ }}$ & 14 & 8,0 & 7.58 & 120 & 36.9 & 50.0 & 280 & 4 & 56 & 2 & 0 & 35 & 2 \\
\hline $\begin{array}{c}19 . \\
\text { Babylon }\end{array}$ & 17 & 7,0 & 7.87 & 140 & 36.3 & 45.1 & 200 & 4 & 59 & 0 & 0 & 34 & 2 \\
\hline $\begin{array}{l}\text { 20. Black } \\
\text { shadowo }\end{array}$ & 13 & 7,5 & 8.09 & 125 & 36.7 & 43.5 & 470 & 2 & 54 & 0 & 0 & 40 & 2 \\
\hline
\end{tabular}

In studying the hematological status, the authors obtained significant differences for most of the studied hematological parameters of blood in the experimental group of horses; with that, the differences with a high degree of accuracy were determined for ESR, leukocytes and segmented neutrophils, with the average degree of certainty for lymphocytes, platelets, and monocytes. A low degree of confidence was found in the number of stab neutrophils, hemoglobin, hematocrit, eosinophils, and erythrocytes.

No significant differences were found in most cases in terms of basophils and the average erythrocytes count.

\section{DISCUSSION}

Traumatism of the distal segments of limbs of sports horses leads to their premature culling. Many authors attribute it to the metabolic disorders that contribute to the development of inflammation in the injured segment.

Authors such as Svetlana Vladimirovna Chernigova, Yuri Vladimirovich Chernigov, Nikolai Vasilievich Babakov in their article titled "Changes in the Level of Cytokines in Treatment of Horses with Acute Traumatic Aseptic Tendovaginitis" state that by the 14th day after the treatment, the animals of the experimental group continued to release large quantities of proinflammatory cytokines on the background of slight activation of the anti-inflammatory mediators. However, by the end of the third week after using the preparations chosen by the authors for the studies Glutoxim - on the background of the cupping the activity of IL-1 $\beta$, IL-6, TNF- $\alpha$, the anti-inflammatory processes are activated, which characterizes the adequacy of the immune response of the animals in this group, and therefore, the appropriateness of the chosen method of treating the horses with injured tendons and ligaments of the distal segments of the limbs. SueDyson MA in her article about sports horses scintigraphy considered this method as highly effective for diagnosing pathologies of the musculoskeletal system of sports horses. The author argues that the use of scintigraphy helped to better understand the mechanics of injuries that occurred to the sports horse. J.-M. Denoix in the article titled " Ultrasonic Study of the Quadriceps Muscle of Thigh: Normal Images and Results" examined the quadriceps muscle of thigh as the reason for lateral kneecap dislocation in a 2-day-old foal. For diagnosing this problem, ultrasound scanning was used. Many Russian and foreign authors studied the methods of treating and diagnosing diseases of the musculoskeletal system in sports horses; however, it was in this article that the comprehensive diagnostics that included more than five tests for detecting limb abnormalities were considered for the first time.

\section{CONCLUSION}

1. It has been found that by the results of the X-ray examination, $25 \%$ of the horses involved in the study were considered conditionally clinically healthy, while in $75 \%$ of the horses, various pathologies of the osteoarticular apparatus were detected.

2. By the results of ultrasonography, $21 \%$ of the horses involved in the study were considered conventionally clinically healthy, while in $79 \%$ of the horses, various pathologies of the tendon-ligament apparatus were detected.

3. Comprehensive examination after comparing the data for $100 \%$ of the horses involved in the experiment with various kinds of limping in the anamnesishas revealed the following: seven (11\%) horses had laminitis complicated by tendonitis of the superficial digital flexor, five (9\%) horses had laminitis without complications, nine (15\%) horses had tendinitis of the superficial digital flexor without complications, five (8\%) horses had knee arthritis complicated by tendonitis of the deep digital flexor, and five (8\%) horses had tendinitis of the deep digital flexor without complications. Also, eight (14\%) horses had knee arthritis without complications, 12 (20\%) horses had bursitis of the ankle joint; fractures of various degrees of complexity with concomitant tendovaginitis of the deep digital flexor were diagnosed in four (6\%) horses, and five (8\%) horses had tendovaginitis of the deep digital flexor without complications.

4. The use of only one visual method of diagnosing diseases of the musculoskeletal system in horses allows assessing the limited area of interest, and cannot be accompanied by the final diagnosis, as it does not allow identifying the pathological state of both the osteoarticular and the tendon-ligament apparatuses. 
5. A significant increase in ESR, the level of leukocytes, segmented neutrophils, and hematocrit was found in the sports horses with diseases of the musculoskeletal and the tendon-ligament apparatuses, which is evidence of the systemic nature of the pathological process.

6. A significant increase in the level of C-reactive protein in the case of diseases of the musculoskeletal system in sports horses is an important marker of the development phase of acute inflammation and for prediction of possible loads in the future.

7. It has been found that the use of nonsteroidal antiinflammatory preparations changes the hematological status of sports horses; therefore, their use should be strictly limited to the duration of treatment (the course of treatment should not exceed three days).

\section{REFERENCES}

1. Breitsher I. L. "Funktsionalnye sistemy sportivnoi loshadi" [Functional systems of sports horses], The tasks of further improving the efficiency of horse breeding arising from the decisions of the 26th Congress of the CPSU,1981, pp. 62 - 63.

2. Budyonny S.M. "Kniga o loshadi. Anatomicheskie i fiziologicheskie osobennosti loshadi'[The book about the horse. Anatomical and physiological features of the horse], M.: Kolos, 1980, Vol. 5, pp. 280310 .

3. S. N. Mager, E. S. Dementieva "Fiziologiya immunnoi sistemy" [Physiology of the immune system], SPb., 2014.

4. David Hodgson, Catherine McGowan, Kenneth McKeever "The Athletic Horse 2nd Edition Principles and Practice of Equine Sports", Medicine, 2013, pp.203-256.

5. Hilary Clayton, Peter Flood, Diana Rosenstein "Clinical Anatomy of the Horse", 2005, pp.30-45.

6. V. S. Sapozhkov "Diagnostika, terapiya i profilaktika tendovaginitov u sportivnykh loshadei" [Diagnosis, therapy, and prevention of tendovaginitises in sports horses]. Veterinary medicine, 5, 2006, pp. 48 $-51$.

7. Y.A. Piluga "Profilaktika deformatsii kopyt u loshadei" [Prevention of hoof deformation in horses], Veterinary medicine, zootechny and biotechnology, 12, 2014, pp. $49-52$.

8. T. S. Ruzanova, V. S. Kashapova "Rannyaya diagnostika patologii sukhozhilno-svyazachnogo apparata loshadi s pomoshchyu UZI" [Early diagnostics of pathologies of the tendon-ligament apparatus of a horse through ultrasound examination] //In collection: Actual problems of AIC development in the works of young scientists of Siberia Proceedings of the XI Regional scientific and practical conference of young scientists of the Siberian Federal district, 2015, pp. 142 - 148.

9. V. N. Alexandrov "Gumoralnyi immunnyi otvet posle travmy razlichnoi tyazhesti" [Humoral immune response after injuries of varying severity], Pathological physiology and experimental therapy, 41, 1983, pp. $70-73$.

10. B. V. Ousha and others "Osnovy rentgenologii i rentgenovskoi semiotiki vnutrennikh boleznei zhivotnykh" [Fundamentals of radiology and $\mathrm{X}$-ray semiotics of internal diseases in animals]. Textbook. M., 2003, p. 50

11. P. D. Gorizontov, O. I. Belousova, M. I. Fedotova. Stress i sistema krovi [Stress and the blood system]. M.: Medicine, 1983.

12. L. H. Ashibokov "Sostoyanie nervnoi sistemy i trenirovannost chistokrovnoi loshadi" [The state of the nervous system and the training status of a blood horse], Horse breeding and horseracing, 3-23, 1970, pp. $12-15$.

13. M. A. Govorova, O. I. Dinchenko, V. M. Byakhova, M. V. Bolshakova "Osobennosti diagnostiki patologicheskikh sostoyanii myagkikh tkanei distalnykh otdelov konechnostei sportivnykh loshadei” [Peculiarities of diagnosing pathological conditions of soft tissues of the distal extremities in sports horses], News of the Orenburg State Agrarian University, 3 (65), 2017, pp. 108-111. 